\title{
The Relationship among Teachers' General Self-efficacy Perceptions, Job Burnout and Life Satisfaction ${ }^{i}$
}

\author{
Osman Tayyar Çelik, Ümit Kahraman* \\ Department of Student Affairs, Pamukkale University, Denizli, 20160, Turkey \\ ${ }^{*}$ Corresponding Author: ukahraman@pau.edu.tr
}

Copyright $\mathrm{C} 2018$ by authors, all rights reserved. Authors agree that this article remains permanently open access under the terms of the Creative Commons Attribution License 4.0 International License

\begin{abstract}
The purpose of this study was to investigate the relationship among teachers' general self-efficacy perceptions, job burnout, and life satisfaction. The participants of the research consist of 412 teachers teaching at the elementary, secondary and high schools. Hypotheses have been developed related to the relationship among variables and a model has been proposed based on these hypotheses. In terms of analyzing the data, confirmatory factor analysis and structural equation modelling were used. As a result of the analysis, it was found that the general self-efficacy perceptions had the negative effects on the job burnout of teachers, and, it was determined that it had a positive effect on life satisfaction but teachers' vocational burnout had negative effect on life satisfaction. It was also found that teachers' vocational burnout played a mediating role between general self-efficacy perceptions and life satisfaction.
\end{abstract}

Keywords General Self-efficacy Perception, Job Burnout, Life Satisfaction, Teacher

\section{Introduction}

The school organization has a complex structure, and many individual and environmental factors can influence the achievement of the school's goals and students' success. However, among these factors, teachers have a key role in reaching the goals. The teachers' knowledge, skills and qualifications have a great importance to fulfil the roles expected. Today, with the rapid changes taking place in every area, new knowledge and skills have been added to the skills that teachers should have and these knowledge and skills are increasing day by day thanks to technological advances. However, intense demands and oppressions on teachers, diminishing resources, and student discipline problems cause stress on teachers leading to exhaustion. When today's rapid changes and general characteristics of the profession are evaluated together, it can be said that teaching is one of the professions under the risk of burnout
[1].

Job burnout is conceptualized as a condition that results from long-term stress exposure among employees who provide human services, especially such as teaching. Despite the various origins, almost all teachers may experience stress in their work [2]. Burnout is a dramatic phenomenon [3] in the teaching, and numerous researches have been conducted since the conceptualization of burnout related to teachers $[4,5,6,7]$ and are still being carried out. Especially in recent research, the effects of school-based environmental factors on teacher burnout have been studied. Problematic student behaviors, managerial demands and school support [7]; time pressure, low student motivation and value dissonance [8]; parental demands and workload [9]; paperwork and difficult students [10] are some of these.

Burnout emerges as a vital problem affecting teachers' lives, their psychological and mental health. Thus, understanding of the reasons and consequences of burnout is very important in terms of teacher performance and student achievement. There are many factors related to teacher burnout. These factors are generally classified as individual and organizational factors [11]. When the domain literature is investigated, it is seen that one of the factors related to the burnout of the teachers within the individual factors is self-efficacy belief $[6,8,12,13]$. As a matter of fact, Leiter [14] describes burnout as a self-sufficiency crisis. Schwarzer and Hallum [15] point out that having self-efficacy traits is a preventive feature in the sense of finding problems and finding solutions in stressful environments. It is argued that individuals who have a positive self-esteem about themselves will be ready to use their resources for the sake of success, and will endeavor to try new experiences unceasingly while performing a profession [16].

One of the important variables studied together with teacher burnout and self-efficacy is life satisfaction. A vocation may influence individuals' life satisfaction in different ways. As a primary means of income, it helps people meet their needs and desires. In addition, vocation occupies a large part of the time left during the day and has 
significant effects on people's self-perceptions and self-esteem [17]. Surveys on life satisfaction reveal that self-efficacy and occupational exhaustion have a significant effect on teachers' life satisfaction [6]. In this context, it is important to develop measures, models and ways to reduce teacher burnout and increase life satisfaction. Intervention programs will be developed, based on these models, will contribute to achieving success but also to the students and the school's goals.

In this study, it was aimed to investigate the relationship among teachers' general self-efficacy perceptions, job burnout and life satisfaction. Hypotheses for the relationship between variables were developed and a model was proposed to be tested. It is thought that the results obtained from the research will shed light on the relationship between the qualifications of the teachers and also may be indirectly influential in student achievement and school effectiveness. In addition, it is hoped that the results of the research will provide guidance to the intervention programs to be developed in taking measures for negative emotions with negative effects on the teachers.

\subsection{Perception of General Self-Efficacy}

Self-efficacy is based on social cognitive theory, which emphasizes that people can influence things they will do [18]. Self-efficacy in social cognitive theory is considered as the beliefs of individuals in capacities that are dominant and specific to a particular situation [19]. It is possible to define self-sufficiency, as the beliefs about capacities of what individuals can or cannot achieve, in other words, how they will perform.

Theoretically, self-efficacy is composed of four basic sources. These are mastery experiences, indirect experiences, verbal persuasion, psychological and emotional states [20]. One of these sources, mastery experiences, is the most effective way of creating a strong sense of competence. The successes and failures that people experience and the conditions they have are influential in the development of self-sufficiency. Another source of self-efficacy is the indirect experience gained by observing other people on similar tasks. At the same time, praise and criticism made by other individuals in the context of verbal persuasion serves as a source of self-sufficiency, as well. Lastly, physical and emotional state, expressions such as anxiety or excitement, which can be interpreted as a sign of sufficiency or inability to overcome the given activities, serve as a source of self-efficacy [21].

Self-efficacy is a multidimensional structure that varies according to the relative time, the circumstances, the attainable assistance, and the time allocated for the task. According to Bandura [22], self-efficacy determines how environmental opportunities and barriers are perceived. Therefore, Bandura emphasizes that people with low self-sufficiency tend to keep up with problems and obstacles. Self-sufficiency as a cognitive symbol of personal beliefs about how individuals are capable to perform certain tasks is influential in the success, optimism, determination, and greater efforts of individuals in challenging conditions $[19,23]$.

Self-efficacy can be specific to a particular area (classroom management, communication, academic, etc.) and is also considered as a phenomenon that can be adapted to the rest of life. This situation is conceptualized as general self-efficacy perception in the domain. General self-efficacy reflects the tendency to see oneself with the ability to successfully influence one's surroundings and achieve the individual's objectives and goals in the living [24]. Indeed, Bandura [19], in his article on self-efficacy theory, points to the generalizability of these perceptions in the same article, although self-efficacy explains that a person is an assessment of his or her perceptions of a certain area (context). According to Bandura, a person can generalize the assessment of talent perception in any context to talent evaluations in similar contexts.

Self-efficacy is a key factor in teacher effectiveness as a belief [8] in planning, organizing, and the ability to accomplish those goals that are necessary to achieve educational goals. In addition, self-efficacy has been shown to be effective in stressful situations and positive effects such as life satisfaction $[25,26]$. In this study, teachers' general self-efficacy was considered as a variable that had an effect on job burnout and life satisfaction.

\subsection{Vocational Burnout}

Burnout is defined as a response to exposure to long-term stress factors [27]. Because of the individual and organizational effects of burnout, many studies focus on theoretical, practical, and solution-oriented research [28]. There is intense interest among researchers around the world for teacher exhaustion, especially since the teaching profession is considered to be one of the professions under the risk of burnout [29].

Initially, the concept of burnout used by Freudenberger [30] was systematically investigated in the field with the scale developed by Maslach and Jackson [31]. Burnout has been conceptualized by researchers as a structure consisting of three different components. These are feelings of emotional exhaustion, insensitiveness and low personal achievement [32]. Emotional exhaustion is thought to be the basic element of exhaustion [33] and is the exhaustion of the individual in emotional resources. Insensitiveness refers to the development of negative and cynical attitudes towards service areas. In this context, teachers who are insensitive can exhibit cold behaviors against students and use depressing expressions on them. As such negative attitudes and behaviors are exhibited, teachers may physically move away from their students and experience psychological withdrawal [27]. Finally, a low sense of personal accomplishment means a belief that 
individuals cannot be effective and successful in fulfilling their assigned tasks.

Burnout reduces the quality of life by negatively affecting both family and business life. Burnout teachers are less concerned with students and other employees and less able to fulfil their roles. The burnout of teachers negatively affects the physical and emotional well-being of the students, which can also negatively affect the classroom atmosphere [34]. Besides these, it is thought that the burnout, which has many effects on the physical, psychological and health aspects of the individuals, will also affect the teachers' life satisfaction. Indeed, jobs that individuals do have an important influence on their life quality. Teacher burnout can also cause a cyclical situation by affecting the life satisfaction of teachers. In this context, in the survey, job burnout was considered as a variable that had an effect on teachers' life satisfaction.

\subsection{Life Satisfaction}

In recent years, positive psychology has focused on positive emotions rather than negative emotions experienced by individuals. In this context, one of the prominent concepts is life satisfaction. Life satisfaction is defined as the subjective well-being of the individual, which expresses the general happiness in life [35]. In the literature, life satisfaction is considered as a component of subjective well-being. Subjective well-being consists of three separate components; positive feelings, negative feelings and life satisfaction. Positive and negative emotions constitute the emotional dimension of subjective well-being while life satisfaction constitutes the cognitive/judicial dimension of subjective well-being [36].

Many studies have been carried out on the factors that influence the life satisfaction of individuals. While the studies focus on individuals with different demographic characteristics, individual and environmental factors are also considered as variables affecting the life satisfaction of individuals. Research on teachers has focused more on the effects of school-based environmental conditions and job characteristics on life satisfaction. Cognitive processes, behavioral characteristics, positive and negative emotions and various personality traits [37], influence the life satisfaction. It has been determined that self-efficacy as a result of teachers' cognitive processes and the effect of burnout on life satisfaction within the scope of negative affect were investigated [38, 26, 39].

The sources of life satisfaction of individuals can be very different. Being happy in daily life, physical well-being, economic situation and social relations are important factors affecting life satisfaction. Crises in the country, economic conditions are closely related to life satisfaction, one of the important determinants of life satisfaction is work and work conditions. An important point that comes to mind when dealing with the quality of life in contemporary societies is subjective perceptions and attitudes about various aspects of work [40]. Individuals spend about $70 \%$ of their time during the day, that is, in $2 / 3$ of their work. Positive attitudes towards jobs help individual provide more satisfaction [41]. Individual evaluations of moods and emotions also reflect on life-satisfaction judgments. Thus, life satisfaction reflects different information for different individuals and varies according to the circumstances at that moment [42]. In this context, it can be said that teachers 'self-efficacy will have an effect on teachers' life satisfaction by determining the situations in which they cope with difficult conditions and reducing the risks of burnout. In this study, general self-efficacy perception and job burnout were considered as variables that affected the teachers' life satisfaction.

\subsection{Research Hypothesis}

According to Bandura [19], self-efficacy is the greatest predictor of our behavior and our emotions. In this respect, it is stated that self-sufficiency is one of the greatest factors that predict burnout [19]. Generally speaking, teachers with larger personal resources and competences (self-efficacy, coping strategies, and professional knowledge) are more likely to cope with the problems of their profession, so they are less likely to experience burnout $[44,15]$. Support for these judgments has also been achieved in the relevant researches as the job burnout of teachers with high self-efficacy is lower [45, 46, 25, 13]. Taking into account theoretical explanations and related research results, the first hypothesis of the research was established as:

"h1. Teachers' perceptions of general self-efficacy significantly predict professional burnout in the negative direction. "

People spend a great deal of their lives in their jobs. Therefore, based on this perceptions of employees, the organizational characteristics can affect the perceptions of employees on life [26]. Life satisfaction is influenced by situations such as achieving desirable things in life, finding meaningful life, determination to achieve goals, positive personality, economic security, social relations and physical well-being. It can be said that the job burnout of teachers will have an effect on the life satisfaction when considering the relation of burnout to many situations mentioned above. Studies in relation to job burnout and life satisfaction $[47,48]$ have identified significant relationships between these variables. The second hypothesis of research based on theoretical explanations and related research results is as:

"h2 Job burnout of teachers significantly predicts their life satisfaction in the negative direction."

Self-efficacy affects human actions through various processes [16]. Individuals' self-efficacy influences how they will continue in the face of the obstacle, how people will feel themselves in their attempt to achieve their goals. Self-efficacy also determines the level of control over 
individuals in life. High self-efficacy individuals have thus more positive emotions rather than negative emotions about the difficult aspects of life. In studies on self-efficacy and life satisfaction, it has been determined that self-efficacy has direct and indirect effects on life satisfaction [49, 35]. Taking into account theoretical explanations and related research results, the third hypothesis of the research was established as;

"h3. The general self-efficacy perceptions of teachers significantly predict the life satisfaction positively."

Competence beliefs determine how environmental opportunities and obstacles are perceived [22], how much time will be spent on activities, and how stable people will be in the face of obstacles. This belief and determination will have a direct impact on the outcome. In addition, when considering the relationship of job burnout with life satisfaction and general self-efficacy perception, mediating effect of job burnout in relation to general self-efficacy perception and life satisfaction comes to mind. In this respect the fourth hypothesis of the research was established as;

"h4. Teachers' job burnout has a mediatory role on the effects of general self-efficacy perceptions on life satisfaction."

A model has been proposed to be tested by researchers based on research hypothesis. The model is presented in figure 1.

\section{Materials and Methods}

\subsection{Participants and Procedure}

Research participants consist of 412 teachers teaching atprimary, secondary and high schools in Turkey's
Malatya province center during the 2017-2018 academic year. The scale forms were applied by researchers by visiting the schools. During the school visits, teachers were informed about the purpose of the research and it was reported that participation was based on volunteerism. After the scale forms were filled, they were collected again by the researchers. $27 \%$ of the participants work in primary schools, $39 \%$ work in secondary schools and $34 \%$ work high schools. $52 \%$ of the participants are females and $48 \%$ of the participants are males.

\subsection{Data Collection Tools}

General Self-Efficacy Scale: A general self-efficacy scale developed by Schwarzer and Jerusalem [50] and adapted to Turkish by Çelikkaleli and Çapri [51] was used to determine the teachers' general self-efficacy perceptions. The scale consisting of ten items and in 5 Likert type ( $1=\mathrm{I}$ do not agree and $5=$ I totally agree) has a one-factor structure. The Cronbach Alpha value of the scale was calculated as .87 .

Burnout Scale: Burnout scale developed by Pines and Aronson [52], of which short form was created by Pines [53] and adapted to Turkish by Çapri [54], was used to determine the professional burnout levels of teachers. The scale consisting of ten items and in 7 Likert type $(1=$ Never and $7=$ Always) has a one-factor structure. . The Cronbach Alpha value of the scale was calculated as .92.

Life Satisfaction Scale: In order to determine the life satisfaction of the teachers the Life Satisfaction Scale developed by Diener, Emmons, Larsen and Griffin [55], adapted to Turkish for teachers by Dağlı and Baysal [56] was used. The scale consisting of ten items and in 5 Likert type ( $1=$ I do not agree and $5=$ I totally agree) has a one-factor structure. The Cronbach Alpha value of the scale was calculated as .82 .

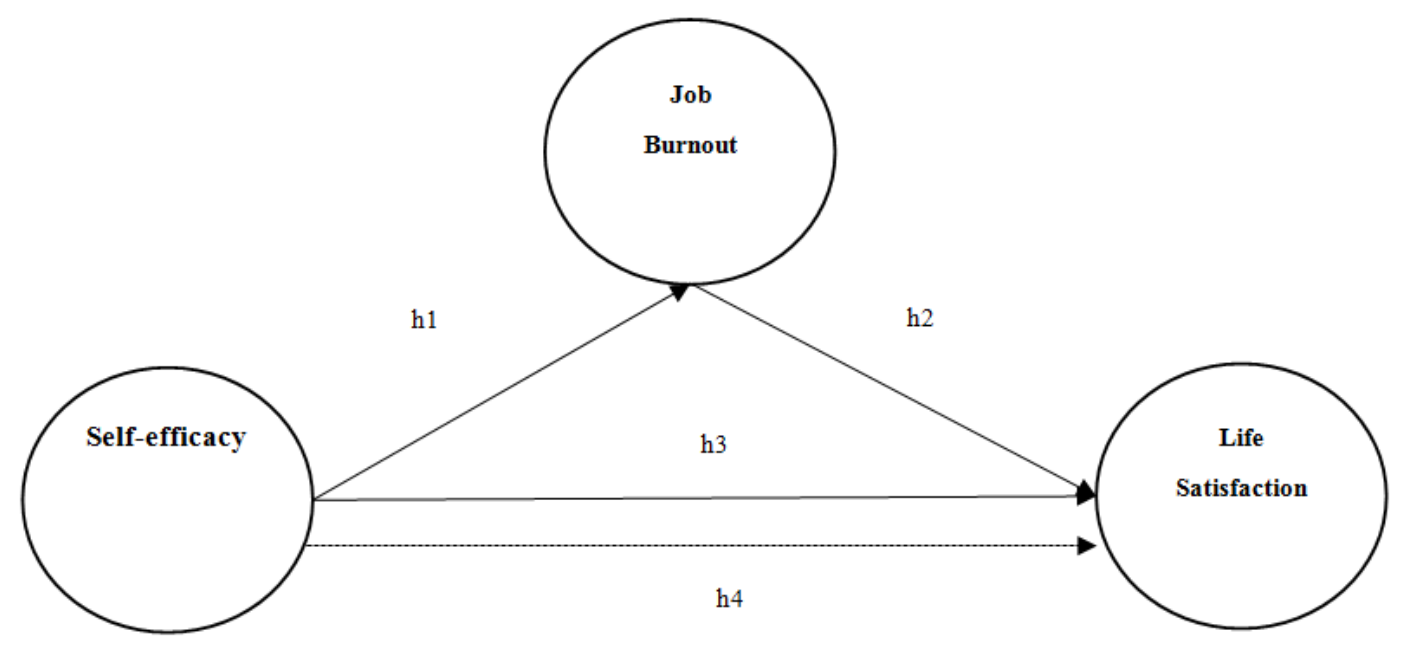

Figure 1. The model to be tested based on research hypothesis 


\subsection{Data Analysis}

Data analysis in the research was carried out in three stages. In the first stage, it is checked whether there is missing data, the critical ratio value and Mardia coefficient are calculated within the scope of multivariable normality, and also whether there is a multiple linear connection is examined by considering the tolerance and VIF values. The Mardia coefficient's being less than 1.96 [57] (the critical value is less than 5), is a measure of the normal distribution [58]. If the VIF values are less than 10 and the tolerance values are bigger than 0.2 , it can be said that there is no problematic multiple linear connections [59]. Within the second step, the measurement model was tested via confirmatory factor analysis. In the last stage, the model proposed by researchers under the framework of research hypothesis has been tested by structural equation modeling. Maximum Likelihood is the most commonly used estimation method in structural equation models. As the normality assumptions were met, the most likelihood estimation method was used in this study. To evaluate the model fit, chi-square / sd ratio, RMSEA, IFI, CFI, TLI compliance values were used by many researchers (Bayram, 2016; Gürbüz \& Şahin, 2014). For IFI, CFI, and TLI goodness values, .90 and .95 are acceptable, .95 and over good fit $[60,61]$. Values of .06 and lower for the RMSEA value are considered good indicators of compliance [61].

\subsection{Results}

In the study prior to the SEM analysis, which is a multi variable statistical method, the critical rate value and the mardia coefficient were calculated in order to examine the assumptions of the multi variable normality. As a result, the Mardia coefficient was found to be 1.8 and the critical ratio (c.r) value was found to be 2.4 , and normality assumptions were met. The tolerance values for job burnout and life satisfaction were calculated as $(.62 ; .53)$ and VIF values $(2.31,2.44)$, and it has been found that there is no multiple correlation between variables. Means, standard deviations and correlations for the research variables are presented in Table 1. There was a moderate negative correlation between general self-efficacy perceptions of teachers and job burnout $(r=-.41)$, a moderate positive relationship between general self-efficacy perceptions and life satisfaction $(r=.34)$ and finally a strong negative relationship between job burnout and life was found $(\mathrm{r}=-52)$.

Table 1. Means, standard deviations and correlations for research variables

\begin{tabular}{|c|c|c|c|c|c|c|}
\hline $\begin{array}{c}\text { Research } \\
\text { Variables }\end{array}$ & $\mathrm{N}$ & Mean & $\begin{array}{c}\text { Standard } \\
\text { deviation }\end{array}$ & 1. & 2. & 3. \\
\hline $\begin{array}{c}\text { General } \\
\text { self-efficacy } \\
\text { perception }\end{array}$ & 412 & 3.82 & 0.89 & 1.00 & & \\
\hline Job burnout & 412 & 3.19 & 0.72 & $-.41 * *$ & 1.00 & \\
\hline $\begin{array}{c}\text { Life } \\
\text { Satisfaction }\end{array}$ & 412 & 3.00 & 0.64 & $.34 * *$ & $-.52 * *$ & 1.00 \\
\hline
\end{tabular}

Note: $* * \mathrm{p}<.05$

Structural equation modeling was done with latent variables and the model was tested by confirmatory factor analysis. The model was found to have acceptable fit indexes $\left(\chi^{2} / \mathrm{sd}=1.826, \mathrm{RMSA}=0.056, \mathrm{IFI}=0.93, \mathrm{CFI}=\right.$ $0.93, \mathrm{TLI}=0.91)$. It was determined that with verification of the measurement model, structural accuracy with the covariance relationship which is about structures is provided, it is also verified that there is no common method variance of data collected from a single source.

Within the framework of research hypothesis, the proposed model for the relationship between variables is tested by structural equation modeling. The standardized regression coefficients obtained after the analysis and the corrected R2 values are presented in FIG 2. In addition, direct and indirect effects are given in Table 2.

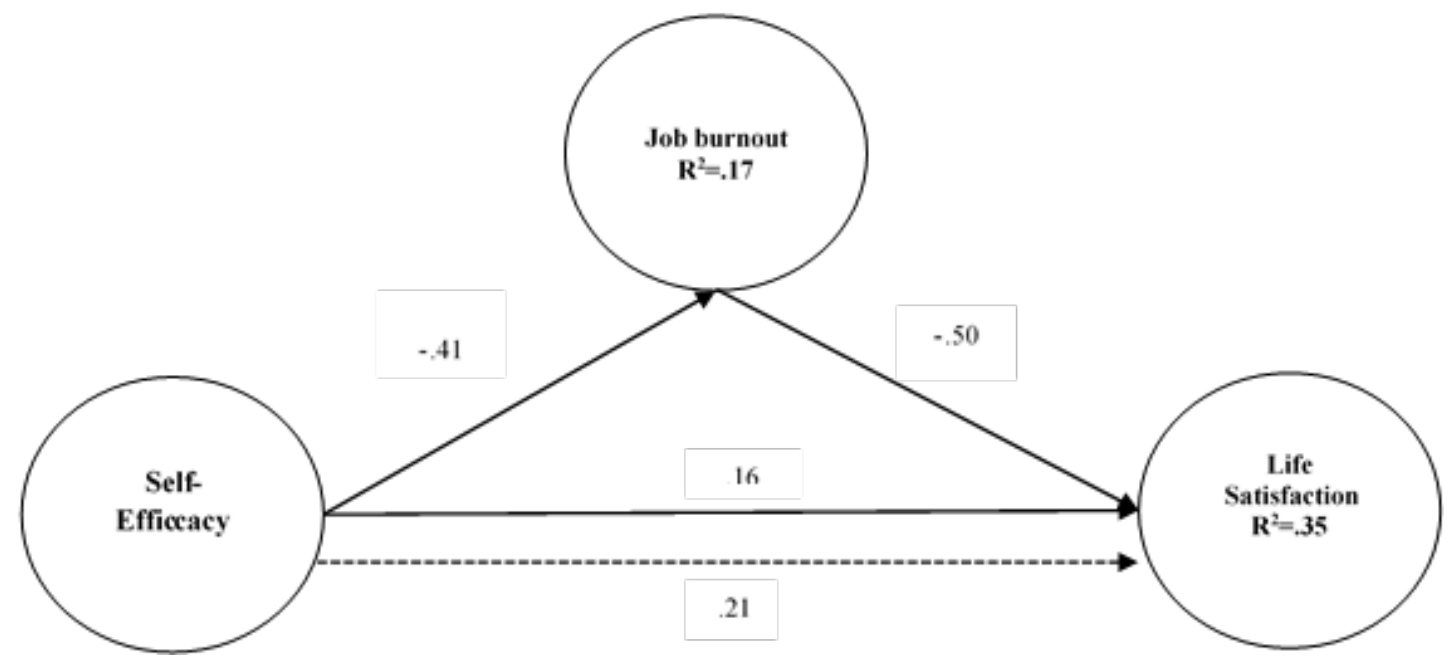

Figure 2. Results of path analysis for relations between variables 
When the standardized path coefficients were examined, it was found that the teachers' self-efficacy perceptions significantly predict the job burnout $(p<.05)$ in the negative direction $(\beta=-.41 ; p<.05)$, the professional burnout significantly predicts the life satisfaction in the negative direction and self-efficacy perceptions predict life satisfaction in the positive direction $(\beta=.16 ; \mathrm{p}<.05)$.

When the adjusted R2 values were examined, it was determined that about $17 \%$ of the variance in the job burnout of the teachers could be explained by the self-efficacy perceptions and about $35 \%$ of the variance in life satisfaction by the model.

Table 2. Direct, indirect and total effects on the model

\begin{tabular}{|c|c|c|c|c|c|c|}
\hline \multirow{2}{*}{$\begin{array}{c}\text { Research } \\
\text { variables }\end{array}$} & \multicolumn{3}{|c|}{ Job burnout } & \multicolumn{3}{c|}{ Life satisfaction } \\
\cline { 2 - 7 } & Direct & Indirect & Total & Direct & Indirect & Total \\
\hline $\begin{array}{c}\text { General } \\
\text { Self-Efficacy } \\
\text { Perception }\end{array}$ & -.41 & & -.41 & .16 & .21 & .37 \\
\hline Job burnout & & & & -.50 & & -.50 \\
\hline
\end{tabular}

When the effects on the model were investigated it was found that teachers' general self-efficacy perceptions have a moderate effect on job burnout (-.41), and a small direct (.16) small indirect (.21) and moderate total (.37) effect on life satisfaction. It was been found that job burnout of teachers has a wide effect size on life satisfaction. One remarkable finding in the study is that teachers' self-efficacy perceptions indirect effect on their life satisfaction is bigger than the direct effect. Indirect effects are also interpreted as mediator effects [62]. Therefore, it can be said that the teachers' job burnout has a mediatory role on the effects of general self-efficacy perceptions on life satisfaction.

\section{Discussion and Conclusions}

In this study, it was aimed to examine the relationship between teachers' general self-efficacy perceptions, job burnout and life satisfaction. Four hypothesis (h1, h2, h3, h4) were developed by researchers based on theoretical explanations and related research results and a model was proposed. As a result of testing the research hypothesis with structural equation modeling, all hypothesis were accepted and the model suggested by the researchers was verified.

The first hypothesis of the research was established as: "h1. Teachers' perceptions of general self-efficacy significantly predict professional burnout in the negative direction. " As a result of the research, it was determined that the teachers' general self-efficacy perceptions significantly predict the job burnout in the negative direction, and teachers' general self-efficacy perceptions have a moderate effect on the job burnout. In researches dealing with the effect of general self-efficacy perceptions of teachers on job burnout $[13,18,25]$, it is concluded that there are negative relationships between the mentioned variables.
In a literature study conducted by Brown [63], it was concluded that teacher burnout is related to self-efficacy perception in a negative way in 10 out of 11 researches, and in the longitudinal study by Lauermann \& König [6], it was revealed that individuals with high self-efficacy experienced less burnout. It has also been reported that self-efficacy also functions as a protective factor for health. Schwerdtfeger, Konermann and Schonhofen [64] investigated primary school and high school teachers and found that there was a significant relationship between self-efficacy, cardiac activities and burnout after examining cardiac movements on normal school day. The most important cause of job burnout is chronic tension. The reason for this tension is incompatibility between job demands and available resources to cope with these demands [64]. An important source of teachers' success in dealing with problems and fulfilling their expected role is strong perceptions of self-efficacy. So, it can be said that teachers' general self-efficacy perceptions are an important determinant in coping with job control and difficulties, and will have an effect on job burnout as an important determinant of success and failure.

The second hypothesis of the research was established as "h2. Job burnout of teachers significantly predicts their life satisfaction in the negative direction. "As a result of the research, it was concluded that the job burnout of the teachers significantly predicts the life satisfaction in the negative direction and that the job burnout has a great influence on life satisfaction. Similar results were achieved in related studies $[10,48,26]$. The level of burnout undoubtedly affects the pleasure and quality of life the concept of life satisfaction, which is related to the individual's well-being, generally expresses the individual's satisfaction with his / her life [65]. Although life satisfaction states a judgement between past, present and future, evaluations of individual's life satisfaction can also be determined by focusing on the flow of daily life. Life satisfaction is related to the living conditions of the individuals and the standards they set. Expectation levels of teachers, occupational statues, economic situations, school-based environmental conditions, inter-employee relations are factors affecting teachers' life satisfaction. As a result, the dissatisfaction, unhappiness, frustration and reluctance in the working life affect the general life of the employees; it can also lead to a decrease in life satisfaction.

The third hypothesis of the research was established as "h3. The overall self-efficacy perceptions of teachers significantly predict the life satisfaction positively." As a result of the research, it was concluded that the teachers' general self-efficacy perceptions significantly affect the life satisfaction in the positive direction. Similar results have been obtained in studies $[35,49,63]$ in which variables are discussed together. Research on life satisfaction has shown that variables such as self-esteem, optimism, and positive emotional experience predict the 
level of life satisfaction of individuals [42]. Self-efficacy affects human actions through various mediatory processes. Self-efficacy perceptions influence how individuals feel about themselves in their attempts to realize goals, whether they will continue against obstacles, and their level of determination. It can be said that the levels of high self-efficacy individuals performing their roles related to their work are more resistant to difficulties. When assessed as the satisfaction level of life expectancy, it can be expressed that personal self-efficacy as a determinant in progressing and positive emotion will also affect life satisfaction.

The fourth hypothesis of the research was established as "h4. Teachers' job burnout has a mediatory role on the effects of general self-efficacy perceptions on life satisfaction. As a result of the research it was concluded that teachers' general self-efficacy perceptions indirectly affect their life satisfaction and job burnout has a mediatory role on this effect. Tschannen-Moran, W. Hoy and Hoy [20] stated that self-efficacy teachers are determined to set goals, self-determined, committed to achieving goals in the face of difficulties, and affecting performance. Maslach and his colleagues have stated that self-efficacy in individuals constitutes a fundamental factor in devoting to work and expresses the antithesis of exhaustion of devotion to work [6]. In this context, it can be said that self-efficacy perception will have an effect on negative and positive emotional life of teachers and indirectly on life satisfaction.

The cognitive and sensitive organizing prior to coping with burnout will equip individuals' sense of control and enables maintaining alternatives. An individual's cognitive and sensitive awareness is the main source for self-efficacy belief. So it can be stated as the self-efficacy belief is the primary source of coping with negative situations like burnout, anxiety and stress. Moreover, considering the complexity of difficulties faced with and their effects on individuals' lives; coping with such difficulties certainly contributes to both life satisfaction and self efficacy by means of one's life goals.

The self efficacy perception is one's belief on his/her own capacity to cope with difficulties. Those with higher self-efficacy can motivate themselves, choose the goals that they can reach, and determined in realizing these goals. Thus it can stated that those individuals having such a wealth are less likely to suffer burnout. Moreover, those individuals having higher self efficacy choose hard goals for themselves and preserve their commitment to them while increasing their strength against failures and thinking that they can easily cope with such situations. Such extra-ordinary perspectives bring personal success.

As a result, it was determined that teachers' general self-efficacy perceptions and job burnout have an effect on life satisfaction, also general self-efficacy perceptions have an effect on life satisfaction via job burnout . Determining ways to improve teachers' self-efficacy perceptions and preparing intervention programs for exhaustion can lead to an increase in the life satisfaction of teachers, indirectly by increasing student outcomes.

\section{REFERENCES}

[1] S. Lim, S. Eo. The mediating roles of collective teacher efficacy in the relations of teachers' perceptions of school organizational climate to their burnout. Teaching and Teacher Education, Vol.44, 138-147, 2014.

[2] H. K. Jennett, S. L. Harris, G. B. Mesibov. Commitment to philosophy, teacher efficacy, and burnout among teachers of children with autism. Journal of Autism and Developmental Disorders, Vol.33, No.6, 583-593, 2003.

[3] A. Brouwers, W. Tomic. A longitudinal study of teacher burnout and perceived self-efficacy in classroom management. Teaching and Teacher education, Vol.16, No.2, 239-253, 2000.

[4] M. B. G. Anderson, E. F. Iwanicki. Teacher motivation and its relationship to burnout. Educational Administration Quarterly, Vol.20, No.2, 109-132, 1984.

[5] Y. Hu. The relationship between job burnout of kindergarten teachers in shanghai and their personality traits. Unpublished doctoral dissertation, University of the Pacific, California, 2017.

[6] F. Lauermann, J. König. Teachers' professional competence and wellbeing: Understanding the links between general pedagogical knowledge, self-efficacy and burnout. Learning and Instruction No.45, 9-19, 2016.

[7] C. J. McCarthy, R. G. Lambert, S. Lineback, P. Fitchett, P. G. Baddouh. Assessing teacher appraisals and stress in the classroom: review of the classroom appraisal of resources and demands. Educational Psychology Review, No.28, 577603,2016 .

[8] E. M. Skaalvik, S. Skaalvik. Still motivated to teach? A study of school context variables, stress and job satisfaction among teachers in senior high school. Social Psychology of Education, Vol.20, No.1, 15-37, 2017.

[9] R. W. Roeser, E. Skinner, J. Beers, P.A. Jennings. Mindfulness training and teachers' Professional development: an emerging area of research and practice. Child Development Perspectives, Vol.6, 167-173, 2012.

[10] M. L. Chang. Toward a theoretical model to understand teacher emotions and teacher burnout in the context of student misbehavior: Appraisal, regulation and coping. Motivation and Emotion, Vol.37, No.4, 799-817, 2013.

[11] Z. Sabuncuoğlu. Turizm İşletmelerinde Örgütsel Davranış. MKM Yayıncılık, Bursa, 2009.

[12] H. Wang, N. C., Hall, S. Rahimi. Self-efficacy and causal attributions in teachers: Effects on burnout, job satisfaction, illness, and quitting intentions. Teaching and Teacher Education, Vol.47, 120-130, 2015.

[13] X. Yu, P. Wang, X. Zhai, H. Dai, Q. Yang. The effect of work stress on job burnout among teachers: The mediating 
role of self-efficacy. Social Indicators Research, Vol.122, No.3, 701-708, 2015.

[14] M. P. Leiter. Burnout as a Developmental Process: Consideration of models. In W. B. Schaufeli, C. E. Maslach, T. E. Marek, (Eds.), Professional Burnout: Recent developments in theory andresearch (pp. 237-249). Taylor \& Francis, Philadelphia, 1993.

[15] R. Schwarzer, S. Hallum. Perceived teacher self - efficacy as a predictor of job stress and burnout: Mediation analyses. Applied psychology, Vol.57, No.1, 152-171, 2008.

[16] A. Bandura. Perceived self-efficacy in cognitive development and functioning. Educational Psychologist, Vol.28, No.2, 117-148, 1993.

[17] R.L. Kahn. Work and Health. Wiley, New York, 1981.

[18] E. M. Skaalvik, S. Skaalvik. Teacher self-efficacy and teacher burnout: A study of relations. Teaching and Teacher Education, Vol.26, No.4, 1059-1069, 2010.

[19] A. Bandura. Self-efficacy: toward a unifying theory of behavioral change. Psychological Review, Vol.84 (2), 191-215, 1977.

[20] M. Tschannen-Moran, A. W. Hoy. The differential antecedents of self-efficacy beliefs of novice and experienced teachers. Teaching and Teacher Education, Vol.23, No.6, 944-956, 2006.

[21] O. P. Malinen, H. Savolainen, P. Engelbrecht, J. Xu, M. Nel, N. Nel, D.Tlale. Exploring teacher self-efficacy for inclusive practices in three diverse countries. Teaching and Teacher Education, Vol.33, 34-44, 2013.

[22] Bandura, A. Adolescent Development from an Agentic Perspective. In F. Pajares \& T. Urdan (Eds.), Self-Efficacy Beliefs of Adolescents (pp. 1-43). CT: Information Age Publishing, Greenwich, 2006.

[23] B. J. Zimmerman. Self-efficacy: An essential motive to learn. Contemporary Educational Psychology, Vol.25, No.1, 82-91, 2000 .

[24] M. Jerusalem, R. Schwarzer. Self-efficacy as A Resource Factor in Stressappraisal Processes. In R. Schwarzer (Ed.), Self-efficacy: Thought Control of action (pp.195-213), DC: Hemisphere, Washington, 1992.

[25] A. Koustelios, N. Tsigilis. The relationship between burnout and job satisfaction among physical education teachers: a multivariate approach. European Physical Education Review, Vol.11, No.2, 189-203, 2005.

[26] B. B. Telef. Öğretmenlerin öz-yeterlikleri, iş doyumları, yaşam doyumları ve tükenmişliklerinin incelenmesi. İlköğretim Online, Vol.10, No.1, 91-108, 2011.

[27] C. Maslach, M. P. Leiter, S. E. Jackson. Making a significant difference with burnout interventions: Researcher and practitioner collaboration. Journal of Organizational Behavior, Vol.33, No.2, 296-300, 2012.

[28] Dolgun, U. Tükenmişlik Sendromu. D. Özler (Ed.), Örgütsel Davranışta Güncel Konular (287-312). Ekin Basım Yayın Dağıtım, Bursa, 2012.

[29] A. M. Aloe, L. C. Amo, M. E. Shanahan. Classroom management self-efficacy and burnout: A multivariate meta-analysis. Educational Psychology Review, Vol.26, No.1, 101-126, 2014.

[30] H. J. Freudenberger. Staff burn - out. Journal of social Issues, Vol.30, No.1, 159-165, 1974.

[31] C. Maslach, S. E. Jackson Maslach Burnout Inventory Manual. Palo Alto, CA: Consulting Psychologist Press, 1986.

[32] D. W. Chan. Burnout and life satisfaction: Does gratitude intervention make a difference among Chinese school teachers in Hong Kong?. Educational Psychology, Vol.31, No.7, 809-823, 2011

[33] W. B. Schaufeli, T. W. Taris. The conceptualization and measurement of burnout: Common ground and worlds apart. Work \& Stress, Vol.19, No.3, 256-262, 2005.

[34] K. Rentzou. Examination of work environment factors relating to burnout syndrome of early childhood educators in Greece. Child Care in Practice, Vol.18, No.2, 165-181, 2011.

[35] R. W. Lent, L. Nota, S. Soresi, M. C. Ginevra, R. D. Duffy, S.D. Brown. Predicting the job and life satisfaction of Italian teachers: Test of a social cognitive model. Journal of Vocational Behavior, Vol.79, No.1, 91-97, 2011.

[36] E. Diener, E. Suh. Measuring quality of life: Economic, social, and subjective indicators. Social Indicators Research, Vol.40, No.1-2, 189-216, 1997.

[37] R. A. Emmons, E. Diener. Personality correlates of subjective well-being. Personality and Social Psychology Bulletin, Vol.11, No.1, 89-97, 1985.

[38] S. Avşaroğlu, M. E. Deniz, A. Kahraman. Teknik öğretmenlerde yaşam doyumu iş doyumu ve mesleki tükenmişlik düzeylerinin incelenmesi. Selçuk Üniversitesi Sosyal Bilimler Enstitüsü Dergisi, Vol.14, 115-129, 2005.

[39] D.A. Camacho. Applying a cognitive-behavioral model to conceptualize burnout and coping for teachers in urban schools. Unpublished doctoral dissertation, Loyola University, Chicago, 2017

[40] P. E. Spector. Job satisfaction: Application, assessment, causes, and consequences. Sage publications, 1997.

[41] İ. Erdoğan. İşletmelerde Davranış. İstanbul İÜ İşletme Fakültesi Yayınları, İstanbul, 1997.

[42] E. Diener, S. Oishi, R. E. Lucas. Personality, culture, and subjective well-being: Emotional and cognitive evaluations of life. Annual review of psychology, Vol.54, No.1, 403-425, 2003.

[43] B. Duffy, J. R. Oyebode, J. Allen. Burnout among care staff for older adults with dementia: The role of reciprocity, self-efficacy and organizational factors. Dementia, Vol.8, No.4, 515-541, 2009.

[44] T. Dicke, P. D. Parker, H. W. Marsh, M. Kunter, A Schmeck, D. Leutner. Self-efficacy in classroom management, classroom disturbances, and emotional exhaustion: A moderated mediation analysis of teacher candidates. Journal of Educational Psychology, Vol.106, No.2, 569-583.

[45] F. D. Betoret. Stressors, self - efficacy, coping resources, 
and burnout among secondary school teachers in Spain. Educational Psychology, Vol.26, No.4, 519-539, 2014.

[46] W. J. Evers, A. Brouwers, W. Tomic. Burnout and self efficacy: A study on teachers' beliefs when implementing an innovative educational system in the Netherlands. British Journal of Educational Psychology, Vol.72, No.2, 227-243, 2002.

[47] R. J. Burke, E. Greenglass. Work stress, social support, psychological burnout and emotional and physical well-being among teachers. Psychology, Health \& Medicine, Vol.1, No.2, 193-205, 2007.

[48] H. Pillay, R. Goddard, L. Wilss. Well-Being, burnout and competence: implications for teachers. Australian Journal of Teacher Education, Vol.30, No.2, 22-33, 2005.

[49] M. J. Gooden-Ledbetter, M. T. Cole, J. K. Maher, A. Condeluci. Self-efficacy and interdependence as predictors of life satisfaction for people with disabilities: Implications for independent living programs. Journal of Vocational Rehabilitation, Vol.27, No.3, 153-161, 2007.

[50] R. Schwarzer, M. Jerusalem. Generalized self-efficacy scale. In J. Weinman, S. Wright, M. Johnston (Eds.), Measures in Health Psychology: A User's Portfolio. Causal and Control Beliefs (pp. 35-37). Windsor, UK: NFER-Nelson, 1997.

[51] Ö. Çelikkaleli, Çapri, B. Genel yetkinlik inancı ölçeği'nin Türkçe formunun geçerlik ve güvenirlik çalışması. Çukurova Üniversitesi Sosyal Bilimler Enstitüsü Dergisi, Vol.17, No.3, 93-104, 2008.

[52] A.M. Pines, E. Aronson. Career burnout: Causes and cures. Free Press, New York, 1988.

[53] A. M. Pines. The burnout measure short version (BMS). International Journal of Stress Management, Vol.12, 78-88, 2005.

[54] Çapri, B. (2013). Tükenmişlik ölçeği-kısa formu ile eș tükenmişlik ölçeği-kısa formu'nun türkçe uyarlaması ve psikoanalitik-varoluşçu bakış açısından mesleki ve es tükenmişlik ilişkisi. Kuram ve Uygulamada Eğitim Bilimleri [Educational Sciences: Theory \& Practice], Vol.13, No.3, 1408-1417, 2013.

[55] E. D. Diener, R. A. Emmons, R. J. Larsen, S. Griffin. The satisfaction with life scale. Journal of personality assessment, Vol.49, No.1, 71-75, 1985.

[56] A. Dağlı, N. Baysal. Yaşam doyumu ölçeğinin Türkçe’ye uyarlanması: geçerlik ve güvenirlik çalışması. Elektronik Sosyal Bilimler Dergisi, Vol.15, No.59, 1250-1262, 2016.

[57] N. Bayram. Yapısal eşitlik modellemesine giriş: Amos uygulamaları. Ezgi Kitabevi, Bursa, 2016.

[58] K. H. Yuan, P. M. Bentler, W. Zhang. The effect of skewness and kurtosis on mean and covariance structure analysis: The univariate case and its multivariate implication. Sociological Methods and Research, Vol.34, No.2, 240-258, 2005.

[59] A. Field. Discovering statistics using SPSS. SAGE Publications Ltd, London, 2005.

[60] B. M. Byrne. Structural equation modeling with AMOS. Routledge/Taylor and Francis Group, New York, 2010
[61] L. T. Hu, P. M. Bentler. Cutoff criteria for fit indexes in covariance structure analysis: Conventional criteria versus new alternatives. Structural Equation Modeling: A Multidisciplinary Journal, Vol.6, No.1, 1-55, 2009.

[62] C.H. Meydan, H. Şeşen. Yapısal eşitlik modellemesi amos uygulamaları. Detay Yayıncılık, Ankara, 2015.

[63] C. G. Brown. A systematic review of the relationship between self-efficacy and burnout in teachers. Educational and Child Psychology, Vol.29, No.4, 47-63, 2012.

[64] A. Schwerdtfeger, L. Konermann, K. Schönhofen. Self-efficacy as a health-protective resource in teachers? A biopsychological approach. Health Psychology, Vol.27, No.3, 358-368, 2008.

[65] A. Keser. İş doyumu ve yaşam doyumu ilişkisi: Otomotiv sektöründe bir uygulama. Çalışma ve Toplum, Vol.4, No.1, 77-95, 2004

\footnotetext{
i This study was supported by Scientific Research Coordination Unit of Pamukkale University under the project number 2018KRM002-088.
} 